\title{
GJJOURNAL
}

Jambura Guidance and Counseling Journal Volume 1 Nomor 2 (November 2020), halaman 83-86 ISSN Online 2722-1628

\section{Expressive Writing with "Jurnaling Technique" Client's Self Exploration Strategy}

\author{
Ilham Khairi Siregar
}

Bimbingan dan Konseling, FKIP, Universitas Muhammadiyah Sumatera Utara, Indonesia

ilhamkhairi@umsu.ac.id

Diterima: October 2020
Abstract
This article contains a number of research results which are summarized into a meta-
analysis paper. Some research results cover the application of journaling counseling
techniques in a broad scope. Counseling services become a very important requirement to
be implemented in the Education unit, especially higher education. Journaling counseling
technique is one of the service efforts provided to clients, so clients can explore, express
emotions and pressures, and analyze them into a coherence that can develop the client's
personality. The author hopes that this article will be a reference source in alleviating
clientproblems and the application of supporting literature display activities.
Keywords: counseling techniques, journaling, literature display
Abstrak
Artikel ini memuat sejumlah hasil penelitian yang dirangkum menjadi sebuah makalah
metaanalisis. Beberapa hasil penelitian mencakup penerapan teknik konseling penjurnalan
dalam ruang lingkup yang luas. Pelayanan konseling menjadi kebutuhan yang sangat
penting untuk dilaksanakan di satuan pendidikan khususnya pendidikan tinggi. Teknik
konseling jurnal merupakan salah satu upaya pelayanan yang diberikan kepada klien,
sehingga klien dapat menggali, mengekspresikan emosi dan tekanan, dan menganalisanya
menjadi suatu koherensi yang dapat mengembangkan kepribadian klien. Penulis berharap
artikel ini dapat menjadi sumber referensi dalam mengatasi permasalahan klien dan
penerapan penunjang kegiatan tampilan literatur.

Kata Kunci: Teknik Konseling, journaling, Tampilan literatur

This is an open access article distributed under CC BY-SA 4.0 AttributionLicense, provided the original workis properly cited. (C)2020 by Ilham Khairi Siregar

\section{INTRODUCTION}

The need for guidance and counseling services is a necessity for education units, both primary and secondary education, and higher education. The provision of guidance and counseling services must be in accordance with the principles of professional guidance and counseling. Counselors as providers of guidance and counseling services that are independent are required to have two main competencies namely academic competence and professional competence (Hidayah, 2010). The current development becomes a benchmark for guidance and counseling services in order to improve the quality of services, both in terms of offline and online services as well as in terms of techniques and strategies that will be applied in the service process. One technique developed is journaling counseling technique. 
Journaling counseling techniques are aids given to clients in order to reduce and alleviate problems related to emotional pressures felt by individuals with expressive writing activities (Lent, 2009). The aim is to express emotionally intensely and create meaning and coherence, write down details of the problem being experienced that causes distress, so that clients are able to analyze it and internalize the results of analysis actively (Dryden, David, \& Ellis, 2010; Kerner \& Fitzpatrick, 2007).

Ellis stated that if individuals are not conditioned to think and feel in a certain way, then they tend to behave in this way, even though they realize that their behavior rejects or negates themselves (Corey, 2016). Other effects of journaling include the expression of feelings, which can lead to greater self-awareness and acceptance and in turn enable the client to create a relationship with himself. Short-term effects of journaling include increased pressure and psychological arousal.

\section{METHODS}

Lent and Young (Erford, 2015) outline the general steps for each journal writing task including: 1) describing the purpose and content of the task, 2) engaging in journaling activities, 3) examining the client's progress and involving the client in meaningful exchanges originating from journal content and process, and 4) encouraging clients and modifying activities when deemed necessary. Journaling also helps keep the counselee focused on the purpose of counseling even when not in a counseling session. This journaling technique was also adopted from the Rational-Emotive Behavioral Therapy (REBT) counseling technique pioneered by Albert Ellis.

\section{RESULTS}

(Kerner \& Fitzpatrick, 2007) conduct research on therapeutic writing that can contribute to physical and psychological benefits. Researchers propose a matrix framework in the process of emotional cognitive change to see these contributions. In the horizontal dimension, writing can encourage clients to reach a certain emotional intensity in order to create meaning and coherence, then in the vertical dimension processes in achieving emotional intensity are activated through structured tasks such as diary writing, autobiographical journals, storytelling and poetry. Other groups in this study experienced obstacles in achieving emotional intensity so that they could not create meaning and coherence. This is due to not using a matrix framework as a process of emotional cognitive change. Based on the observations of researchers, the matrix framework is a proposal for therapists to use writing strategies in therapy.

(Dryden et al., 2010) suggested that by writing down the details of the problems / dynamics that are being experienced by the client and causing distress, so the client is able to actively analyze and internalize the results. (Lent, 2009) examines the technology applied in counseling practices with clients. Information technology in the form of blogging media, clients are asked to write a journal as a counseling intervention that is a means of self-exploration and publicizing the thoughts and feelings of clients. (Utley \& Garza, 2011) conducting research on adolescents, namely discussing and giving examples of journalizing in counseling. The therapist reads the client journaling script and is asked to 
reflect on it. Based on the client's self-reflection on the journal he was presenting, the therapist saw a decrease in traumatic symptoms.

(Smyth, Hockemeyer, \& Tulloch, 2008) based on the results of the study explaining expressive writing can improve mood and growth for PTSD patients in the control group. Expressive writing can weaken cortisol's response to a patient's memory of trauma. Although expressive writing does not reduce the intensity of trauma, expressive writing can increase the patient's capacity in managing trauma, so that the patient's physiological response decreases and results in faster recovery. (Keeling \& Bermudez, 2006) conducted a four week study of an innovative externalization of sculpture and journaling. The findings show that interventions help participants in expressing emotions, participants are aware of the resources they have, and are able to separate themselves from problems experienced by participants, reduce symptoms and problematic behavior, and foster selfempowerment.

\section{CONCLUSION}

Based on the exposure of several studies put forward by researchers, journal writing, expressive writing, also called journaling counseling techniques. This can be analyzed from the theory of approach used, namely REBT theory by Albert Ellis which suggests that if individuals are not conditioned to think and feel in a certain way, then they tend to behave in this way, even though they realize that their behavior refuse or negate yourself (Corey, 2016). This theory is often used by both therapists and counselors in treating clients.

Analyzing various research problems by researchers using journaling counseling techniques including those related to individual cognitive, such as undisclosed emotions, trauma to a condition or the impact of pent-up emotions, psychological symptoms that cause stress and other cognitive symptoms. Henceforth the theory of this approach can also be tested on the problems experienced by individuals in order to make them develop optimally.

\section{REFERENCES}

Corey, G. (2016). Theory and Practice of Counselling and Psychotherapy (10 ed.). Diambil dari https://ebookcentral.proquest.com/lib/acap/detail.action?docID=4643533.

Dryden, W., David, D., \& Ellis, A. (2010). Handbook of Cognitive-Behavioral Therapiess. In K. S. Dobson (Ed.), Cognitive Behavioral Therapies (3 ed., hal. 226). London: The Guilford Press.

Erford, B. T. (2015). 40 Teknik yang Harus Diketahui Setiap Konselor (2 ed.; H. P. Soetjipto \& S. M. Soetjipto, ed.). Yogyakarta: Pustaka Pelajar.

Hidayah, N. (2010). Process-Audit Dalam Penyelenggaraan Pendidikan Akademik Jenjang S-1 Bimbingan Dan Konseling. Jurnal Pendidikan dan Pembelajaran (JPP), 17(2), $129-139$.

Keeling, M. L., \& Bermudez, M. (2006). EXTERNALIZING PROBLEMS THROUGH ART AND WRITING: EXPERIENCE OF PROCESS AND HELPFULNESS. Journal of Marital and Family Therapy, 32(4), 405-419. https://doi.org/10.1111/j.1752-0606.2006.tb01617.x 
- Ilham Khairi Siregar

Kerner, E. A., \& Fitzpatrick, M. R. (2007). Integrating Writing into Psychotherapy Practice: A Matrix of Change Processes and Structural Dimensions. Psychotherapy, 44(3), 333-346. https://doi.org/10.1037/0033-3204.44.3.333

Lent, J. (2009). Journaling Enters the 21st Century: The Use of Therapeutic Blogs in Counseling. Journal of Creativity in Mental Health, 4(1), 67-73. https://doi.org/10.1080/15401380802705391

Smyth, J. M., Hockemeyer, J. R., \& Tulloch, H. (2008). Expressive writing and posttraumatic stress disorder: Effects on trauma symptoms, mood states, and cortisol reactivity. British Journal of Health Psychology, 13(1), 85-93. https://doi.org/10.1348/135910707X250866

Utley, A., \& Garza, Y. (2011). The Therapeutic Use of Journaling With Adolescents. Journal of Creativity in Mental Health, 6(1), 29-41. https://doi.org/10.1080/15401383.2011.557312 